\title{
Angiomyolipoma of the Nasal Cavity Resected with Preoperative Angio-Embolization
}

\author{
Sang Hyeon Ahn ${ }^{1}$, Yong Ju Lee ${ }^{2}$, Chang-Hoon Kim ${ }^{1}$ and Jung Hyun Chang ${ }^{2}$ \\ ${ }^{1}$ Department of Otorhinolaryngology, Yonsei University College of Medicine, Seoul; and \\ ${ }^{2}$ Department of Otorhinolaryngology, National Health Insurance Corporation, Ilsan Hospital, Goyang, Korea
}

\author{
색전술 후 내시경적 절제술을 시행한 비강 내 혈관근육지방종 1예 \\ 안상현 $^{1} \cdot$ 이용주 $^{2} \cdot$ 김창훈 $^{1} \cdot$ 장정현 $^{2}$ \\ 연세대학교 의과대학 이비인후과학교실, ${ }^{1}$ 국민건강보험공단 일산병원 이비인후과학교실 ${ }^{2}$
}

\author{
Received February 7, 2013 \\ Revised April 22, 2013 \\ Accepted April 22, 2013 \\ Address for correspondence \\ Jung Hyun Chang, MD, PhD \\ Department of Otorhinolaryngology, \\ National Health Insurance \\ Corporation, Ilsan Hospital, \\ 100 Ilsan-ro, Ilsandong-gu, \\ Goyang 410-719, Korea \\ Tel $+82-31-900-0346$ \\ Fax $+82-31-900-0613$ \\ E-mail manbang5@naver.com
}

\begin{abstract}
Angiomyolipomas (AML) are generally known as benign tumors. The kidney is the most common location of this tumor, and the liver is reported as the second most common site. Occurrence in other tissues is extremely rare. For instance, some cases of AML originating from the nasal cavity have been previously reported. We describe an AML case arising from the nasal cavity of a 56-year-old man. The patient had been complaining of nasal obstruction and foreign body sensation in the nasopharynx and was initially treated with preoperative angio-embolization. AML was then totally removed by endoscopic surgery without complications. He has been asymptomatic and has had no evidence of recurrence for 2 months after surgery.

Korean J Otorhinolaryngol-Head Neck Surg 2013;56:528-31

Key Words Angiomyolipoma $\cdot$ Endoscopic surgical procedure $\cdot$ Nasal cavity $\cdot$ Therapeutic embolization.
\end{abstract}

\section{Introduction}

Angiomyolipomas (AML) are benign tumors composed of a mixture of mature fat tissues, smooth muscle cells, and smallto-medium-sized, thick-walled blood vessels in various proportions. ${ }^{1)}$ This tumor usually occurs in the kidney. Outside the kidney, the liver is the second most common site. Only a few cases have been reported in the mediastinum, heart, spermatic cord, vaginal wall, Fallopian tube, oral cavity, pharynx, nasal cavity, and skin. ${ }^{2)}$ In particular, AML originating from the nasal cavity has been previously reported only eight times. We present an additional case of AML arising from the nasal cavity, which was resected completely with endoscopic surgery after angio-embolization. In addition, we describe clinical features compared with previously reported cases of nasal cavity AML.

\section{Case}

A 56-year-old man who had been complaining of nasal obstruction and foreign body sensation in the nasopharynx visited ENT clinic. The patient had taken medication for diabetes mellitus several years before but had no other medical history, including tuberous sclerosis (TS). On physical examination, a hyper-vascular, bulging mass was noted on the floor of the left posterior nasal cavity, and the posterior septum was deviated toward the right nasal cavity due to the mass effect of the growing tumor (Fig. 1). Paranasal sinus computerized tomography (PNS CT) showed that the enhanced heterogeneous mass, which was not distinguished from surrounding tissue, involved the left posterior choana. Endoscopic incisional biopsy at anterior portion of mass under local anesthesia was conducted to confirm pathology. Postoperative bleeding was minimal, but was not controlled easily by epinephrine 


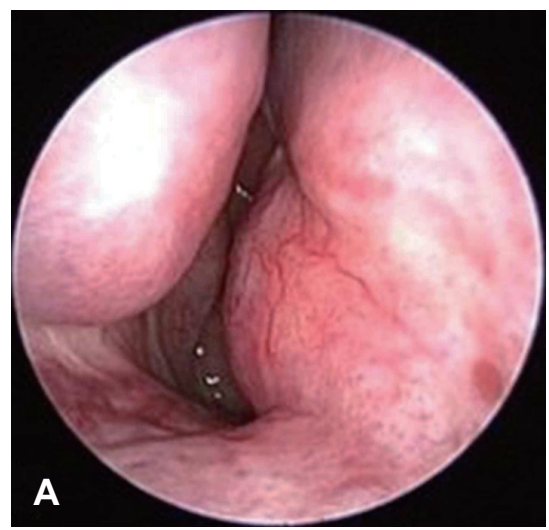

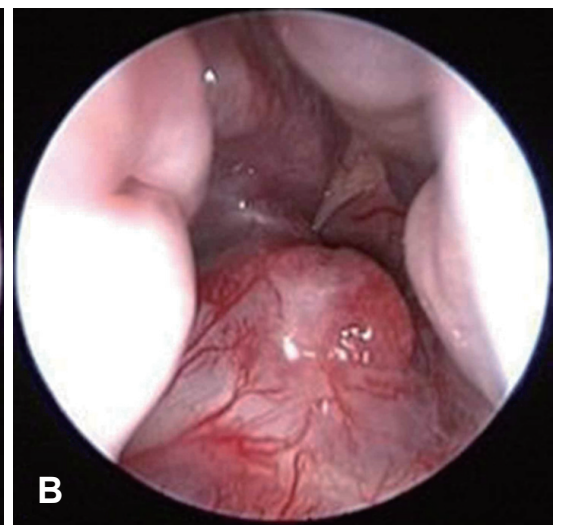

Fig. 1. Endoscopic images show a bulging, hyper-vascularized mass located on the floor of the left posterior nasal cavity. The posterior septum was deviated toward the right nasal cavity. Right nasal cavity (A). Left nasal cavity (B).
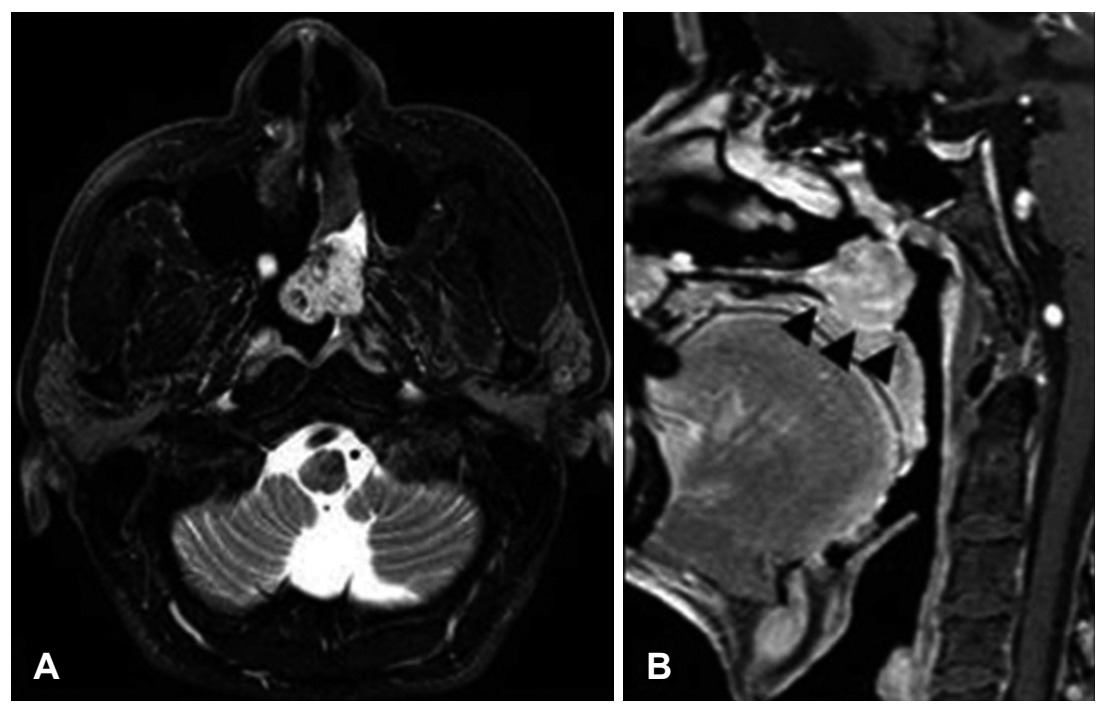

Fig. 2. Neck MRI shows a $2.5 \times 1.5 \mathrm{~cm}$, enhancing mass located on the left posterior nasal floor without bony erosion and demarcated from surrounding tissue (arrows)(B). T2-weighted neck MRI shows an internal fatty component with decreased signal on fat saturation sequence. The remaining portion of the mass had strong contrast enhancement. Axial view of T2-weighted neck MRI (A). Sagittal view of T2-weighted neck MRI (B).
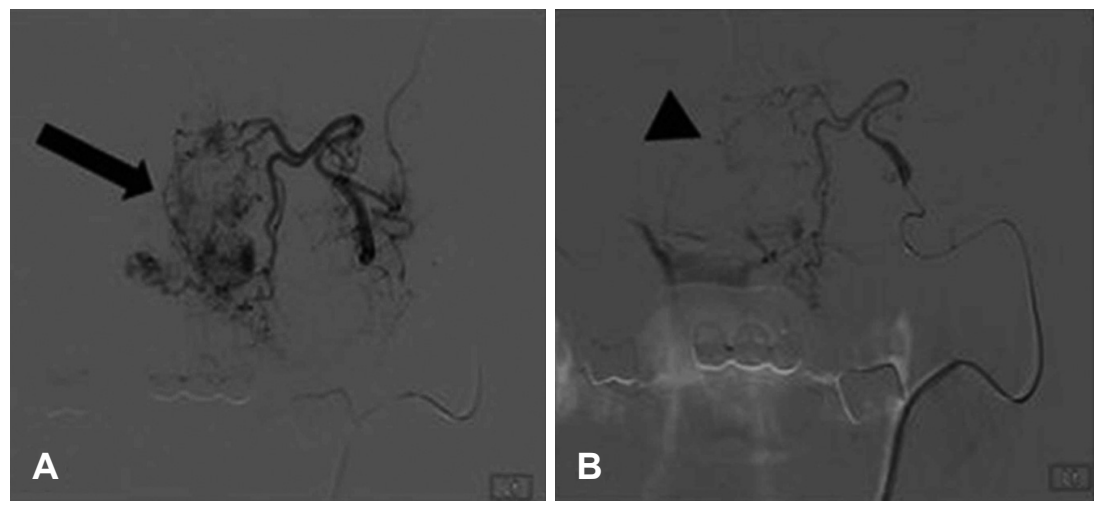

Fig. 3. Tumor stain was noted from branches of the left internal maxillary artery. Successful embolization using PVA was performed after super selection of the feeders. Arrow indicates hypervascular mass before embolization. Head of arrow shows successful postembolization. Pre-embolization (A). Postembolization (B). PVA: polyvinyl alcohol.
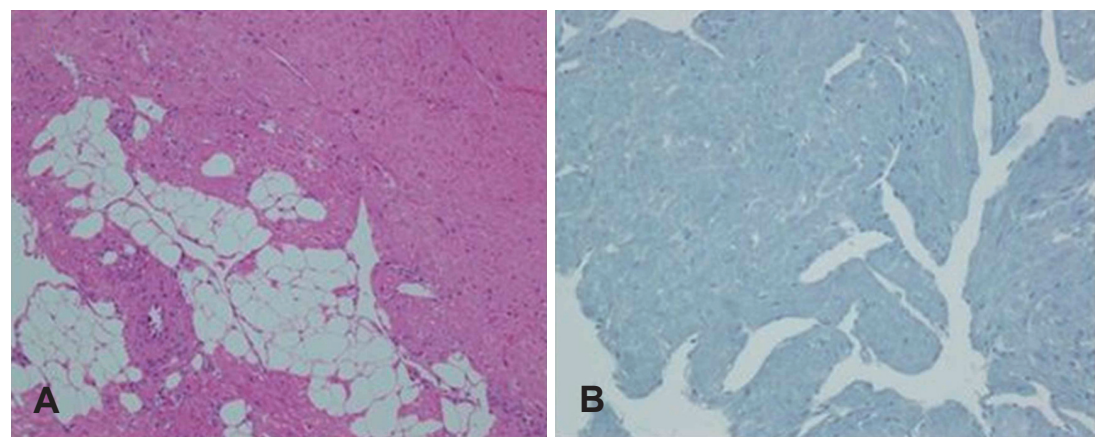

Fig. 4. Histopathology demonstrates a tumor composed of various fatty tissues, proliferated vessels, and smooth muscle cells, suggesting angiomyolipoma. Also it shows negative for HMB-45 on immunohistochemistry. Hematoxylin and eosin original $\times 100$ (A). HMG$45 \times 200$ (B). 
gauze. Pathologic diagnosis was reported as AML. Neck MRI was performed in order to determine surgical approach and to confirm the extent of the tumor and vascular structures, especially relationship between tumor and soft palate (Fig. 2). It revealed a $2.5 \times 1.5 \mathrm{~cm}$ enhancing mass located on the left posterior nasal floor without bony erosion. The tumor was clearly defined from surrounding tissue and had an internal fatty component with decreased signal on fat saturation sequence. Remain portion of the mass showed strong contrast enhancement. Because of tumor had hyper-vascularity in image and bleeding control had not been easy, we performed a preoperative angiogram to identify the feeding vessel. Branches of the left internal maxillary artery were then embolized with polyvinyl alcohol $(250-350 \mu \mathrm{m})$ (Fig. 3).

The next day, the patient underwent nasal endoscopic resection, which revealed a protruding smooth mass located on the inferior floor of the left posterior nasal cavity. The tumor extended to the soft palate but exhibited no adhesion to surrounding tissue. The lesion was resected without bleeding or other complications. Histologically, the tumor was composed of fatty tissues, proliferated vessels, and smooth muscle cells, suggesting AML. Immunohistochemical staining was positive for Desmin and smooth muscle actin and negative for CD 34 and HMB-45 (Fig. 4). Abdominal pelvic CT revealed no evidence of kidney or liver invasion. The patient was discharged without complications five days after the operation. He has been asymptomatic and without recurrence during two months of follow-up.

\section{Discussion}

AML are known as benign tumors, usually arising from the kidney. Some cases have been reported in the liver, mediastinum, heart, spermatic cord, vaginal wall, Fallopian tube, oral cavity, pharynx, nasal cavity, and skin. ${ }^{2)}$ AML originating in the nasal cavity is rare and differs from renal AML in several ways. Watanabe and Suzuki ${ }^{2)}$ proposed that such tumors in the skin and nasopharyngeal mucosa should be categorized as mucocutaneous angiomyolipomas, distinct from AML of the kidney and liver. AML in the nasal cavity includes only mature smooth muscle cells and is negative to HMB-45 melanoma specific antigens on immunohistochemical staining, unlike renal AML. Nasal cavity AML also tends to occur in older men, is never associated with TS, and is smaller than renal or hepatic AML, which tend to be larger than $40 \mathrm{~mm}$.

Generally, the clinical symptoms and radiologic findings

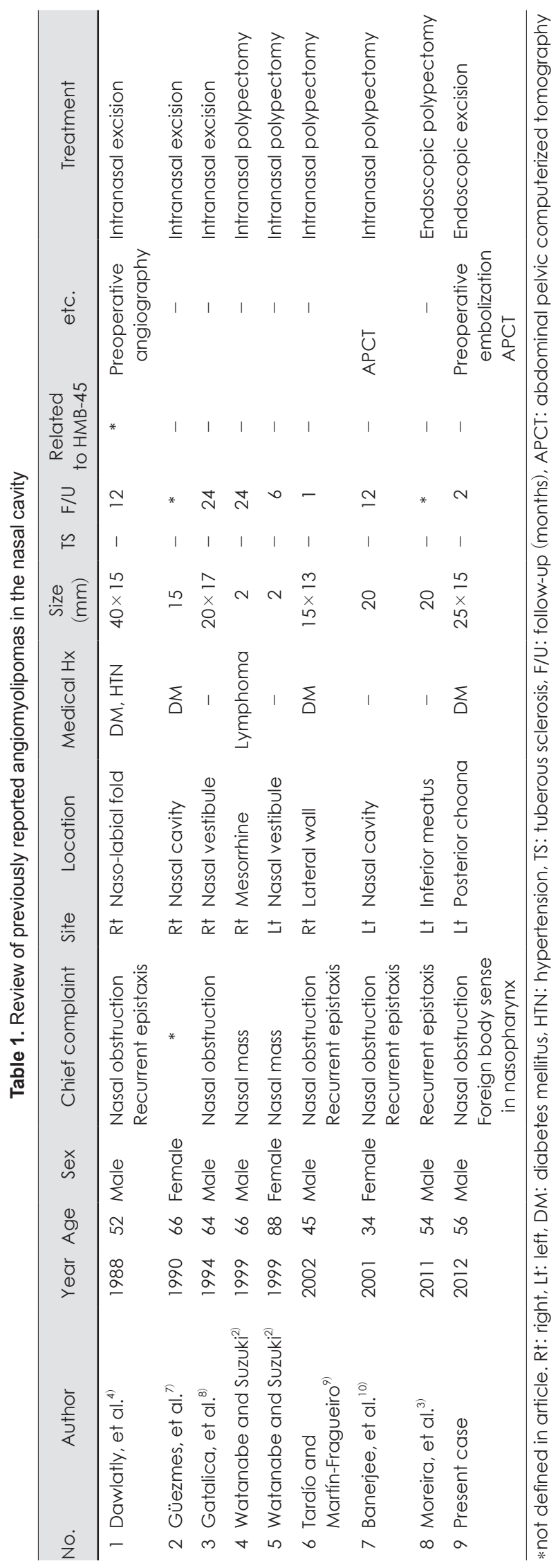


of these nasal cavity masses are nonspecific. The most commonly encountered hamartomas arising from the nasal cavity and nasopharynx are angiofibromas and hemangiomas. ${ }^{4}$ Angioleiomyomas are vascular tumors that are often pedunculated, but these tumors have been reported only rarely. ${ }^{5}$ ) Final diagnosis was based on the histologic examination. ${ }^{4}$ Pathologic features of previous cases of AML in the nasal cavity include various-sized vessels, mature smooth muscle cells, and fat cells.

Eight cases of AML in the nasal cavity have been previously reported. Table 1 briefly shows the clinical features of each case, including our most recent case. The patients were six men and three women, aged 34 to 88 years (mean 58.33 years). Patients mainly complained of nasal obstruction in five cases. Recurrent epistaxis was the second chief symptom in four cases. In our case, the patient complained of nasal obstruction and foreign body sensation in the nasopharynx after eating. Tumors were located in various places, from the naso-labial fold to the posterior choana. Five cases were located on the right side and four on the left side. Four patients had taken medication for diabetes mellitus. Previous reports show that about $80 \%$ of cases of TS were related to AML. Renal AML was closely associated with the occurrence of TS, and half of patients with renal AML also had TS. ${ }^{2,6)}$ None of the cases of nasal cavity AML were related with TS. Furthermore, all cases of nasal cavity AML were negative to HMB-45 staining; however, one patient did not undergo the test. Tumor size varied between 2 to $40 \mathrm{~mm}$ with mean of $17.7 \mathrm{~mm}$. Follow-up ranged from 1 to 24 months, and no patient had evidence of recurrence. Preoperative angiogram was performed in only one case, as the feeding vessels from a branch of the facial artery were ligated at the level of mandible during the operation. Another patient had an abdominal pelvic CT that dem- onstrated no kidney or liver involvement. AML in the nasal cavity did not coexist with renal or hepatic AML by abdominal pelvic $\mathrm{CT}$.

This case is the first report of an endoscopic resection with preoperative angio-embolization for AML in nasal cavity. Although AML like this case was located on the posterior nasal floor, which was a difficult area to approach, endoscopic resection was possible without leaving remnant tumor, if there is no evidence of adhesions on preoperative imaging. Furthermore, preoperative angio-embolization may minimize bleeding risk for hyper-vascular mass on nasal cavity.

\section{REFERENCES}

1) Bonetti F, Pea M, Martignoni G, Doglioni C, Zamboni G, Capelli P, et al. Clear cell ("sugar") tumor of the lung is a lesion strictly related to angiomyolipoma--the concept of a family of lesions characterized by the presence of the perivascular epithelioid cells (PEC). Pathology 1994;26(3):230-6.

2) Watanabe K, Suzuki T. Mucocutaneous angiomyolipoma. A report of 2 cases arising in the nasal cavity. Arch Pathol Lab Med 1999; 123(9):789-92.

3) Moreira MD, Lessa MM, Lima CM, Lessa HA, Fonseca Júnior LE. Angiomyolipoma of the nasal cavity. Braz J Otorhinolaryngol 2011; 77(2):269.

4) Dawlatly EE, Anim JT, el-Hassan AY. Angiomyolipoma of the nasal cavity. J Laryngol Otol 1988;102(12):1156-8.

5) McCaffrey TV, McDonald TJ, Unni KK. Leiomyoma of the nasal cavity. Report of a case. J Laryngol Otol 1978;92(9):817-9.

6) Erkiliç S, Koçer NE, Mumbuç S, Kanlikama M. Nasal angiomyolipoma. Acta Otolaryngol 2005;125(4):446-8.

7) Güezmes A, Mazorra F, García-Mantilla F, Eizaguirre MJ, Ondiviela R. [Nasal angiomyolipoma]. Acta Otorrinolaringol Esp 1990;41(5): 341-2.

8) Gatalica Z, Lowry LD, Petersen RO. Angiomyolipoma of the nasal cavity: case report and review of the literature. Head Neck 1994;16(3): 278-81.

9) Tardío JC, Martín-Fragueiro LM. Angiomyolipoma of the nasal cavity. Histopathology 2002;41(2):174-5.

10) Banerjee SS, Eyden B, Trenholm PW, Sheikh MY, Wakamatsu K, Ancans J, et al. Monotypic angiomyolipoma of the nasal cavity: a heretofore undescribed occurrence. Int J Surg Pathol 2001;9(4):309-15. 